\section{Flagellate dermatitis following consumption of shiitake mushroom}

\author{
Hui Voon Loo, Hazel H. Oon \\ National Skin Centre, Singapore
}

Abstract

Japanese dermatologists were the first to describe the very characteristic flagellate dermatitis following consumption of undercooked or raw shiitake mushroom (Lentinus edodes). These similar eruptions were also reported in patients treated with bleomycin, in dermatomyositis and adult onset Still's disease. We report a case where a 40 year old chinese female developed flagellate dermatitis following ingestion of a bun containing shiitake mushroom.

\section{Introduction}

Flagellate literally means to whip (someone), either as a religious discipline or for sexual gratification according to Oxford Dictionary. Flagellate dermatitis or toxicoderma presents with very characteristic linear wheal like skin manifestations and is often associated with shiitake mushroom (Lentinus edodes). It was first described by Nakamura in $1985 .^{1}$ We report a 40 year old lady who developed flagellate dermatitis following ingestion of a bun containing shiitake mushroom.

\section{Case Report}

A 40 year old lady complained of acute onset of unusual rashes on her neck, body and limbs for 2 days. She reported feeling itchy on her arms and kept scratching, but denied scratching her trunk. She denied taking any medications. Physical examination revealed extensive flagellate dermatitis on arms, trunk, legs, neck, forehead and some pinpoint petechiae on arms (Figure 1). On further questioning, patient recalled eating portobello mushroom from an Italian restaurant 5 days ago and a mushroom bun from a bakery shop 3 days ago, but could not recall taking shiitake mushroom. She recalled having itch when she ate mushroom in the past but no rash.

Her full blood counts, liver function tests, creatine kinase and creatinine were normal. Her ANA was a low titre at 1:100 (speckled). She received oral prednisolone and antihistamines.

\section{Discussion}

On further clarification with the bakery shop, the mushroom bun that she ate 3 days prior to the onset of rash contained shiitake mushroom. She was advised to avoid shiitake Mushroom in future. Her rash improved subsequently.

Flagellate dermatitis typically presents with multiple intensely pruritic, erythematous linear plaques and papules on the trunk and extremities. ${ }^{2}$ Such cutaneous reactions often occurred 48 hours following ingestion of under-cooked or raw shiitake mushroom. ${ }^{3}$ The average duration of involvement was 8.5 days and improvement was generally noticed within 2 to 14 days. $^{4}$

People involved in cultivating and marketing shiitake mushrooms may develop allergic alveolitis on inhalation of mushroom spores and contact dermatitis upon contact with the mushroom. They may have positive patch tests and specific IgE antibodies. However, in shiitake dermatitis, skin prick and patch tests were mostly negative except for a few cases report by Lipper. ${ }^{3}$ There was a suggestion of possibility of UVA photodermatosis by Hanada during which $47 \%$ of patients with shiitake dermatitis had reproducible skin lesions to UVA on phototesting but not with UVB. ${ }^{5}$ Histology findings are nonspecific. Acutely, the skin biopsy shows spongiosis, elongated rete ridges with infiltrates of degenerative epidermal cells, lymphocytes, eosinophils and dermal oedema with perivascular infiltrates of lymphocytes, neutrophils, and eosinophils. ${ }^{4}$

The exact underlying pathogenesis is still uncertain. Koebnerisation was postulated by Nakamura, although scratching did not reproduce the eruptions. ${ }^{4}$ Lentinan, a polysaccharide found in shiitake has been implicated by a direct toxic effect, leading to interleukin-1 secretion, causing vasodilation, haemorrhage and the eruption. ${ }^{5}$ Heat may play a role in denaturing the toxin as flagellate dermatitis mostly only occurs in patients who consumed the under-cooked mushroom. ${ }^{4}$

Flagellate dermatitis was also reported in patients treated with bleomycin, in dermatomyositis ${ }^{6}$ and HIV patients. ${ }^{7}$ In bleomycin-induced flagellate dermatitis, patients developed linear pruritic pigmented lesions between 1 day and 9 weeks after the administration and may recur upon rechallenge of the drug. It was reported to occur, in a dose dependent manner, in about 8 to $66 \%$ of patients treated with bleomycin. Some patients may develop such eruptions even with a very low dose of bleomycin. ${ }^{8}$ Three cases of AIDS patient with Kaposi's sarcoma treated with relatively low dose of bleomycin were also reported to develop pruritic flagellate dermatitis. ${ }^{6}$ During the
Correspondence: Hazel H. Oon, National Skin Centre 1, Mandalay Road, Singapore 308205.

Tel. 65.62534455 - Fax: 65.62533225 .

E-mail: hazeloon@nsc.gov.sg

Key words: flagellate dermatitis, shiitake mushroom, lentinan poisoning.

This paper has not been published or submitted for publication elsewhere.

All authors have contributed significantly and are in agreement with the content of the manuscript.

Conflict of interest: the authors have no conflict of interest. There are no financial or personal relationship between the authors and others that could bias the work set out in the manuscript.

Received for publication: 23 July 2011.

Accepted for publication: 10 August 2011.

This work is licensed under a Creative Commons Attribution NonCommercial 3.0 License (CC BYNC 3.0).

(C) Copyright H.V. Oon et al., 2011

Licensee PAGEPress, Italy

Dermatology Reports 2011; 3:e21

doi:10.4081/dr.2011.e21

acute phase of bleomycin-induced flagellate dermatitis, the histological findings are similar to fixed drug eruption. This includes basal vaculolar alteration, pigmentary incontinence, dyskeratotic keratinocytes and perivascular dermal infiltrates of lymphocytes and eosinophils. Ultrastructurally, there is increased contact time between melanocytes and keratinocytes from the decrease in epidermal turnover, with the melanocytes being arrested in a pigment-producing state. Some authors suggested that since the skin lacks hydrolase which inactivates bleomycin, the local accumulation of bleomycin in skin could result in inflammatory reactions, similar to that of a fixed drug eruption. The hyperpigmentation may be postinflammatory rather than a primary sign. Nevertheless, the dermatitis resolves with cessation of bleomycin but hyperpigmentation can persist up to eight months. ${ }^{9}$

Previously, it was thought that this was class specific to bleomycin. In 2007, there was a case report of a patient developing flagellate erythema after three days treatment with docetaxel for metastatic breast cancer. Her pruritus and erythema resolved spontaneously with resolution of pigmentation gradually over weeks. ${ }^{10}$

Rarely, patients with dermatomyositis present with centripetal flagellate erythema on the trunk and proximal extremities. The histological findings showed interface dermatitis. Such unusual eruptions have not been reported in other types of connective tissues dis- 
Table 1. Characteristics of flagellate erythema found in different conditions.

\begin{tabular}{|c|c|c|c|c|c|}
\hline & $\begin{array}{l}\text { Shiitake flagellate } \\
\text { dermatitis }\end{array}$ & $\begin{array}{l}\text { Bleomycin-induced } \\
\text { flagellate erythema }\end{array}$ & $\begin{array}{l}\text { Dermatomyositis } \\
\text { associated flagellate } \\
\text { erythema }\end{array}$ & $\begin{array}{l}\text { Adult onset Still's disease } \\
\text { associated flagellate } \\
\text { erythema }^{10}\end{array}$ & $\begin{array}{l}\text { HIV associated } \\
\text { flagellate erythema }\end{array}$ \\
\hline Clinical features & $\begin{array}{l}\text { 1. Pruritic erythematous } \\
\text { linear papules, sparing } \\
\text { the inaccessible areas } \\
\text { to scratching on the back } \\
\text { 2. Triggered by } \\
\text { under-cooked/raw Shiitake } \\
\text { mushroom, commonly } 48 \text { hrs } \\
\text { after ingestion } \\
\text { 3. Intense pruritus, } \\
\text { usually no pigmentation }\end{array}$ & $\begin{array}{l}\text { 1. Hyperpigmented brownish } \\
\text { linear streaks } \\
\text { 2. Occurs } 1 \text { day to } 9 \text { weeks } \\
\text { post administration } \\
\text { of bleomycin in a } \\
\text { dose-dependant manner } \\
\text { 3. Pruritus maybe absent, } \\
\text { pigmentation present }\end{array}$ & $\begin{array}{l}\text { 1. Centripetal reddish linear } \\
\text { streaks with erythematous } \\
\text { plaques } \\
\text { 2. Mirrors the disease } \\
\text { severity } \\
\text { 3. Pruritus present, } \\
\text { usually no pigmentation }\end{array}$ & $\begin{array}{l}\text { 1. Persistent plaques with } \\
\text { linear pigmentation with } \\
\text { or without coalescent } \\
\text { erythematous plaques } \\
\text { 2. Presence could indicate } \\
\text { a worse prognosis with } \\
\text { increased risk of systemic } \\
\text { complications and longer } \\
\text { time to remission } \\
\text { 3. Pruritus and pigmentation } \\
\text { may be present }\end{array}$ & $\begin{array}{l}\text { 1. Linear flagellate plaques } \\
\text { accompanying fever } \\
\text { and eosinophilia } \\
\text { 2. HIV patients with } \\
\text { hypereosinophilic } \\
\text { syndrome }\end{array}$ \\
\hline Histology & $\begin{array}{l}\text { Non-specific } \\
\text { (spongiosis, elongated rete } \\
\text { ridges, eosinophils } \\
\text { and lymphocytes infiltrates, } \\
\text { dermal oedema) }\end{array}$ & $\begin{array}{l}\text { Similar to fixed drug eruption } \\
\text { in the acute phase } \\
\text { Post-inflammatory } \\
\text { hyperpigmentation in late } \\
\text { lesions }\end{array}$ & Interface dermatitis & $\begin{array}{l}\text { Dyskeratotic cells in the } \\
\text { epidermis and dermal } \\
\text { infiltrates of neutrophils }\end{array}$ & $\begin{array}{l}\text { Mixed perivascular infiltrate } \\
\text { with eosinophils, } \\
\text { histiocytes, lymphocytes } \\
\text { and eosinophils } \\
\text { Presence of flame bodies }\end{array}$ \\
\hline Treatment & $\begin{array}{l}\text { Topical and oral } \\
\text { corticosteroids, } \\
\text { antihistamines } \\
\text { Self-limiting } \\
\text { Thoroughly cooked Shiitake } \\
\text { for future consumption }\end{array}$ & $\begin{array}{l}\text { Discontinue bleomycin } \\
\text { Short course of oral/ potent } \\
\text { topical corticosteroids } \\
\text { Self-limiting }\end{array}$ & $\begin{array}{l}\text { Topical /oral corticosteroids } \\
\text { and immunosuppresants } \\
\text { (topical calcineurin inhibitors, } \\
\text { hydroxychloroquine) } \\
\text { Responds well to } \\
\text { conventional therapy }\end{array}$ & $\begin{array}{l}\text { Main aim is to treat the } \\
\text { underlying systemic disease } \\
\text { Oral corticosteroids and } \\
\text { immunosuppressants } \\
\text { (methothrexate, cyclosporin) } \\
\text { May persist even after fever } \\
\text { has subsided }\end{array}$ & $\begin{array}{l}\text { Oral and topical } \\
\text { corticosteroids, } \\
\text { PUVA }\end{array}$ \\
\hline
\end{tabular}
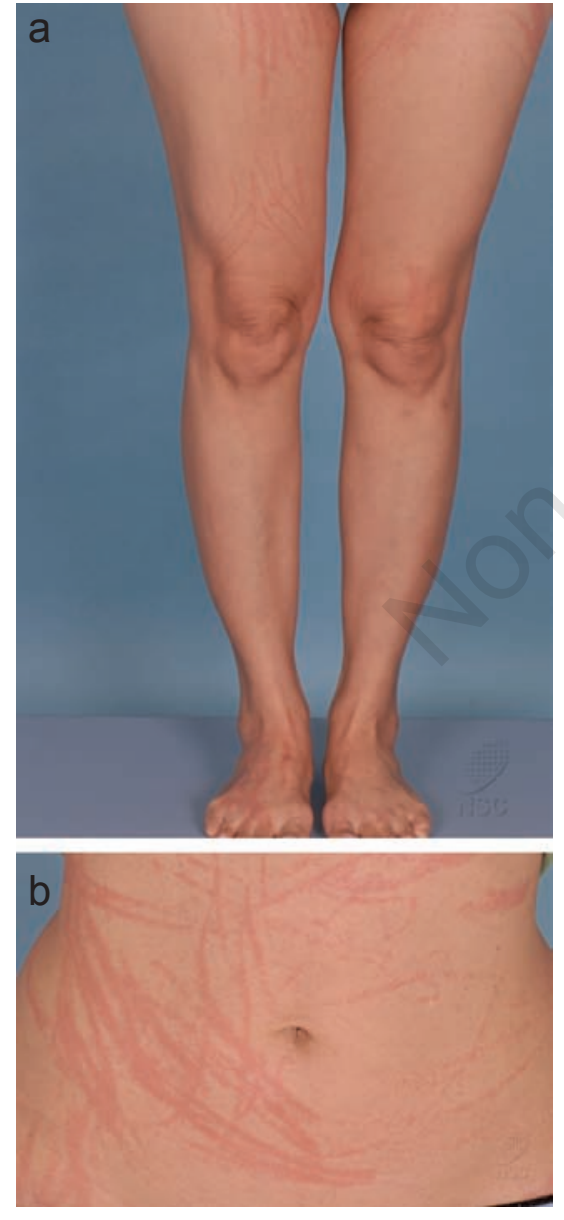

Figure 1. Linear grouped erythematous papules on lower limbs (a) and abdomen (b). ease except for adult onset Still's disease. The intensity of the flagellate dermatitis purportedly mirrors the disease severity of dermatomyositis and may indicate a more complicated course of disease in adult onset Still's disease. ${ }^{6,11}$ Even less commonly, HIV patients with hypereosinophilic syndrome were also reported to present with unusual cutaneous manifestations of linear flagellate plaques. ${ }^{7}$

\section{Conclusions}

Flagellate erythema was initially described in patients who consumed raw or undercooked shiitake mushroom. However, such eruptions are also characteristic of several diseases, each having their own distinguishing clinical features. Shiitake mushroom is the second most cultivated mushroom in the world and was reported to have immunomodulatory effects. ${ }^{4}$ Perhaps a wise move would be to consume the thoroughly cooked mushroom so that this delicious delicacy could be savoured without adverse effects.

\section{References}

1. Nakamura T, Kobayashi A. Toxicodermia cause by the edible mushroom shiitake (Lentinus edodes). Hautarzt 1985;36:591-3.
2. Arseculeratne G, Berroeta L, Meiklejohn D, et al. Bleomycin-induced flagellate dermatitis. Arch Dermatol 2007;143:1461-2.

3. Lippert U, Martin V, Schwertfeger C, et al. Shiitake dermatitis. Br J Dermatol 2003; 148:178-9.

4. Nakamura T. Shiitake (Lentinus edodes) dermatitis. Contact Dermatitis 1992;27: 65-70.

5. Hanada K, Hashimoto I. Flagellate mushroom (Shiitake) dermatitis and photosensitivity. Dermatology 1998;197:255-7.

6. Nousari HC, Ha VT, Laman SD, et al. Centripetal flagellate erythema: a cutaneous manifestation associated with dermatomyositis. J Rheumatol 1999;26:692-5.

7. May LP, Kelly J, Sanchez M. Hypereosinophilic syndrome with unusual cutaneous manifestations in two men with HIV infection. J Am Acad Dermatol 1990;23 (2 Pt 1):202-4

8. Nandwania R, Money-Kyrle J, Hawkins DA, et al. Bleomycin-induced flagellate dermatitis in AIDS patients with Kaposi's sarcoma. J Eur Acad Dermatol Venerol 1995; 4:89-95.

9. Vuerstaek J.D, Frank J, Poblete-Gutiérrez P. Bleomycin-induced flagellate dermatitis. Intern J of Dermatol 2007;46:3-5.

10. Tallon B, Lamb S. Flagellate erythema induced by docetaxel. Clin Exp Dermatol 2007;33:276-7.

11. Yamamoto T, Nishioka K. Flagellate erythema. Int J Dermatol 2006;45:627-31. 